\title{
Glossy Postcards and Virtual Collectibles: Consuming Cinematic Paris
}

\author{
Isabelle McNeill, University of Cambridge
}

\begin{abstract}
This article examines the touristic consumption of Paris in cinema, through a concept of the cinematic postcard as a commodification of history and place, arguing that film participates in and also illuminates touristic relations to the city. The article proposes two iterations of the cinematic postcard: a 'glossy' postcard that incorporates past and present into a cohesively framed urban space, and 'virtual collectibles' that encourage the serial accumulation of familiar signs of place. While connected through a nostalgic relation to the urban past, these iterations reflect different anxieties about the city and are emphasised in different aesthetic strategies, which the article pursues through close analysis of two films: Vincent Minnelli's An American in Paris (1951) and Woody Allen's Midnight in Paris (2001). In the troubled Paris of the early postwar years, the tourist gaze of cinema provided a cohesive image constructed from a selective, cultural past, anticipating a postmodern aesthetic of nostalgia as identified by Fredric Jameson. In the age of what Boris Groys calls 'total tourism' and its proliferation of the collection and online display of images of place, the emphasis has shifted from transmission to the virtual collection of desirable, analogue images of Paris.
\end{abstract}

\section{Keywords}

Paris, postcards, tourism, nostalgia, cinema, Internet

\section{Introduction}

The tourist has long been a derisory figure, condemned only to perceive, 'that which has been discovered by entrepreneurship and prepared for him by the arts of mass publicity' (Fussell 1980: 38-9). Tourists are barred from an authentic experience of place, which they merely consume. In tourism, places are mediated by the 'global sign industries', including cinematic depictions of exotic or historic sites, which shape the international image of locations and direct the focus of the tourist gaze (Tzanelli 2007: 9). Nevertheless, tourism expresses longings otherwise unfulfilled by daily life, a desire for transport and discovery: 'tourism is the search for this reality that has been stolen, it is the search for a full, deep life rather than a shallow one, it is the search for authentic experiences' (Corrigan 1997: 137). In the age of social media, however, where tourism implies a proliferation of the collection and online display of images, the touristic search for authenticity has increasingly embraced mediation. While the 'full, deep life' continues to be desirable, it is sought through a mediated relation to places and their history, captured in a personalised set of iconic images and captions that are collected and shared. 
In this article, I examine questions of mediation and authenticity in the evolving relation between cinema and tourism. I draw on a concept of the cinematic postcard (Liz 2014), which I develop to emcompass a relation to time as well as place. Focusing on Paris as an exemplary site of urban and cinematic tourism highlights the the way cultural heritage - a city's past - is circulated and consumed through cinema. Considering the cinematic postcard as a commodification of both time and space, I propose two different iterations of the concept: a 'glossy' postcard that incorporates past and present into a cohesively framed urban space, and 'virtual collectibles' that encourage the serial accumulation of familiar signs of place. These iterations are not entirely separable, but are nonetheless foregrounded in different aesthetic strategies. Postmodern theory is helpful in conceptualising the implication of both tourism and cinema in a global marketplace of circulating signs. Yet we must now understand the cinematic consumption of place in the current context of 'total tourism' (Groys: 2008), where the reproduction and dissemination of place has become allencompassing. Screens make us tourists in our daily lives: "the "virtual window" has become a ubiquitous portal [...] to pasts and futures' (Friedberg 2006: 242). Moreover, in this information age, digital consumption online opens up 'an apparently limitless list of desirable goods' (Molesworth and Knott 2012: 229), making fervent, virtual, collectors of us all.

Having established a theoretical framework in the first part of the article, my analysis then advances through close readings of two films from very different moments in time, both of which perform a cinematic tour of Paris: An American in Paris (Vincente Minnelli, 1951) and Midnight in Paris (Woody Allen, 2011). By examining how these films repackage historic Paris for touristic consumption, I highlight both continuities and discontinuities in the way the city has been consumed, cinematically and touristically, through the era of mass tourism. There are significant differences between the two films; I will show that rather than exemplifying a modern/postmodern divide, they reflect a world before and after the Internet. Minnelli's 1950s musical already anticipates a postmodern cinematic tourism in its exuberant commodification of Parisian imagery, while aspects of the later film signal a present-day context of digital, virtual appropriation of place, even while nostalgically excluding representations of contemporary information technology. A close study of these films' relation to place shows how film participates in yet may also illuminate contemporary touristic relations to the city, in which 'reproducibility' has become the ultimate value of a tourist location.

\section{Sign Industries: From Tourism to 'Total Tourism'}

The affinities between tourism and cinema have been observed by cultural theorists and sociologists. ${ }^{1}$ Ewa Mazierska and John K. Walton point out that travel and cinema both, 'derive from human curiosity [...] and respond to a desire to escape from mundane reality' (2006: 5). Indeed, John Urry and Jonas Larsen argue that this longing to step out of one's ordinary existence is a fundamental feature of tourism (2011: 10). Cinema, in its conjuring of different times and places, seems to respond to similar desires. Cinema allows us to travel without moving, much as tourism can be a way of seeing something different without really shifting our perspectives. Moreover, it is now widely acknowledged that cinema and tourism have become profoundly interrelated in what Rodanthi Tzanelli terms the 'global sign industries' (2007: 9). ${ }^{2}$

Tzanelli argues that the contemporary structures of both tourism and cinema go beyond the distinctions between production and consumption on which Marxist 
critiques of consumer society have been predicated. Tourists, she claims, 'never seem to consume specific objects, but clusters of signs', in 'a game of endless hermeneutics' (8-9). Here the interpretative activity of hermeneutics encompasses both production and consumption, moving away from an idea of tourists and spectators as simply passive recipients. Tzanelli's argument draws on Jean Baudrillard's conception of a world of circulating signs. Baudrillard argued that the logic of the market is all-consuming, penetrating not only external aspects such as labour and products but also our inner lives (Baudrillard 1998: 191). In this vision, the dialectics of appearance and reality have lost their purchase: 'There is no longer anything but the transmission and reception of signs' (ibid). This conception of consumerism takes us beyond the opposition of authenticity and inauthenticity in traditional discourses about tourism, reconfiguring these terms as signifiers, each referring to the other, and to a wider, related spectrum of social signifiers (for example of cultural or economic status). As early as 1973, Dean MacCannell argued that, 'for the study of tourist settings, front and back [should] be treated as ideal poles of a continuum, poles that are linked by a series of front regions decorated to appear as back regions, and back regions set up to accommodate outsiders' (602). However, the logic of Baudrillard's theory undoes the very concept of 'tourist settings', since, when everything is a sign, there are no longer contrasting, authentic places devoid of what MacCannell termed 'staged authenticity'.

Both tourism and cinema collaborate in a global industry of signs that is constantly reconfiguring and commodifying urban space. In the twenty-first century, however, the circulation of signs has proliferated online. Photo and video-sharing websites, online streaming and social networks enable billions of 'users' to upload, browse, store, list, register interest in ('like') and purchase - among myriad other things - images and tours of places. For Internet users, travel and cosumption are ever more tightly intertwined. We experience the web as a spatial network that must be navigated as well as browsed. Grappling with new modes of digital and virtual consumption, scholars have described consumers on the auction site eBay as developing, 'forms of advanced flânerie' (Molesworth and Knott 2012: 228). Such wandering, gazing and seeking is driven, argue Molesworth and Knott, by familiar structures of consumer desire that are reconfigured, requiring new navigational and tactical skills, and producing new interactions with desired objects. In particular, via the 'wishlists' of popular retail websites such as Amazon, we partially actualise a virtual commodity, 'changing the status of an item to a possession in waiting' (Molesworth and Knott: 227).

I propose that such 'partial actualization' encompasses many other forms of clickable appropriation such as 'pinning' images on Pinterest or saving videos to lists on YouTube. Since they are structurally similar, these activities merge seamlessly with the uploading and broadcasting of photographic documentation of our lives and travels on sites like Facebook and Flickr, activities which are arguably just as acquisitive. As social commentator Jacob Silverman puts it: 'Social broadcasts are not communications; they are records of existence and accumulating metadata' (2015: 47). Much of our lives are now spent capturing and amassing collections of signs in the form of electronic images, videos and text: 'living in the moment means trying to capture and possess it' (Silverman 2015: 58). Collecting 'possessions in waiting' has never been easier, but paradoxically the overwhelming possibilities demand extra labour as we develop refined expertise in filtering and categorisation, not only of information online, but also of the world as we seek out relevant sites and sights with our 'Facebook eye' (Jurgenson 2012). This emphasis on capture recalls Susan 
Stewart's conception of the collection, which she distinguishes from the souvenir. Whereas the souvenir evokes an origin, a commodity standing in for some unique experience of a place, the collection effaces origin in favour of seriality (1984: 151-3). Moreover, the collection conceals the labour of production of the objects, replacing it with the leisurely 'labour' of the collector: 'the collection presents a metaphor of "production" not as "the earned" but as "the captured" [...] If [collections] are "made," it is by a process that seems to invent itself for the pleasure of the acquirer' (164-5). Although Stewart's model is concerned with physical objects, her emphasis on 'capture' remains helpful for evoking the way both internet activities and tourism have shifted emphasis away from the preservation of memories (origin), converging instead around the leisurely work of collecting.

Such proliferation of 'user-driven content' also increases the mobility of place, even as we spend more time static before our screens. This movement of travelling signs is reflected in Boris Groys's concept of 'total tourism', where, 'all manner of people, things, signs, and images drawn from all kinds of local cultures [...] are leaving their places of origin and undertaking journeys around the world (Groys 2008: 104). ${ }^{3}$ For Groys the contemporary era of total tourism exceeds even as it encompasses traditional 'romantic tourism', where the individual travels in order to find a particular form of experience monumentalized in the city. Instead, in total tourism, the city multiplies itself and circulates globally as a 'world city':

What fascinates us nowadays is precisely not locally defined differences and cultural identities but artistic forms that persistently manage to assert their own specific identity and integrity wherever they are presented. Since we have all become tourists capable only of observing other tourists, what especially impresses us about all things, customs, and practices is their capacity for reproduction, dissemination, self-preservation, and survival under the most diverse local conditions.

(Groys 2008: 106)

The consumption of place through virtual reproduction and dissemination has become the norm, and we no longer expect to discover 'reality' that way, as we might have done when, in the earliest days of cinema, the Lumière brothers captured and circulated cinematographic images of the world. On the contrary, we seek the familiar and recognisable put into play in a new game: 'survival under the most diverse local conditions', as Groys puts it. As spectator-tourists, we are reassured to discover that Paris is indeed a moveable feast (I will return to this phrase of Ernest Hemingway's). A city's reproducibility is precisely what makes it beautiful; it is desirable as a partially actualised possession in waiting.

\section{Cinematic Postcards: Framing the Past}

In their process of selection, capture, framing and mobilisation, postcards exemplify the commodification of place that emerged in earlier eras of tourism. Following on from earlier nineteenth-century visual and photographic genres, postcards afforded a cheap means of portioning out a city's views into portable, marketable communications and souvenirs. Citing Naomi Schor's analysis of early twentiethcentury postcards as a nationalistic and nostalgic iconography of Paris (1992: 213), scholars describe cities as being 'postcarded' (Prochaska and Mendelson 2010: xii; Diffrient 2015: 596). In the production of postcards, in other words, urban sights have 
been parsed, framed and turned into objects of consumption: 'The postcard reduced the new urban industrialized world in dimension and made it into a packaged, personal event, one that promised a satisfactory relationship to a shadow of the thing itself' (Rabinovitz 2012: 100). As Lauren Rabinovitz points out, these personalized, miniature, and domestic qualities of the postcard differentiate it from cinema, with its larger-than-life, projected mobility (2012: 99). She goes on, however, to suggest that the parallels between the two are in fact more fundamental, arguing that, 'the postcard and the cinema (which emerged at the same historical moment) are both novelty mechanical accommodations to the shocks of the new' (ibid.) Arising at a moment when the modern city had begun to feel like a bewildering and alienating space, both postcards and cinema offered a means of taming and possessing the city, creating the impression that, 'modern cities and industrial life also contained their own sublime order - oases of space and time for exoticizing all that was considered modern' (Rabinovitz 2012: 107). Postcards and cinema can both be seen, in other words, to respond to anxiety about the embodied experience of modern urban space. They filtered excitement at the new through a tempering nostalgia, whether in their 'preference for depicting the medieval core of the city' (Prochaska and Mendelson: 2010: xii) or in the 'exoticizing' and ordering way new buildings and monuments were represented, which also reveals a nostalgia for the more manageable experience of the pre-modern city.

Given these connections it is unsurprising that scholars have sought to understand cinematic depictions of place by analogy with the postcard. Alastair Phillips locates the myths of Paris in Robert Siodmak's La Vie Parisienne (1936) in the context of the picture postcard, among other 'social practices' of spectacle emerging at the end of the nineteenth century (1999: 29). For David Scott Diffrient, the postcard's serial and selective display of place is reflected in what he calls, 'postcard cinema', or 'serially emplotted, metrophilic films that contain episodes collectively offering a series of fleeting "snapshots" (2015: 590). Diffrient draws on the work of Schor and Stewart in his article, and through his focus on omnibus films he is drawn to the seriality of the postcard collection, described by Schor as a collector herself. I contend, however, that it is important to differentiate between the postcard as souvenir, with its emphasis on transmission, and the collection, which may include postcards, now primarily valued in terms of serial 'collectibility' rather than because of their connection with an original site. As argued above, in the Internet era the latter has become the dominant mode of consumption of place. This is reflected in cinema where, as Carol Vernalis speculates, 'our engagements with media are increasingly based on smaller units. We remember a fragment from a film and connect it to a moment in a YouTube clip or a music video' (2013: 13). While films that focus on a particular city may function as a postcard, capturing and transmitting an image of it for touristic consumption, elements and fragments of films may function as collectibles, to be selected and accumulated. While this is to an extent a result of changing modes of audience engagement, my analyses below of the two films will show that their aesthetic and narrative construction pre-empts and foregrounds modes of postcard-like consumption very differently in different eras.

The term 'cinematic postcard' is defined by Mariana Liz in an article that takes the eclectic omnibus film Paris, Je T'Aime (Assayas et al., 2006) and the sombre Match Point (Allen, 2005) as examples. For Liz, a cinematic postcard is determined firstly by its content, such as famous monuments, as well as the 'feel, atmosphere and character of specific cities' (Liz 2014: 7) and is conceptual as well as visual (7). Liz further defines the cinematic postcard in terms of a certain practice of 
tourism: 'consumed in a brief moment, postcards seem designed to do away with the time (and potentially the need) for reflection, instead aiming for a widely accepted view of the place represented' (5). Liz's primary aims are to demonstrate that postcard-like films are significant features of contemporary European cinema, and that, in a parallel movement, such films play an important role in shaping the perception of European cities at an international level. Most interesting in her argument, however, are the implications for temporality. Liz invokes the postcard's power to endow a 'timeless feel' (5) through a cohesive, static image and by analogy a stereotypical image of a city, be it a shot of London's 'gerkin' tower or a narrative structured by its class system, to take Match Point as an example. Although Liz does not pursue this idea, beyond an acknowledgement of the importance of heritage in a city's touristic image, the characterization of the postcard as something to be 'consumed in a brief moment', points to the compression of historical time brought about in a timeless image of a city, designed to be recognised and appreciated in an instant. Film is, of course, a particularly apt medium for enfolding multiple historical moments into its multi-layered text, offering conveniently condensed spatio-temporal tours of the city. I propose that nostalgia is a key component of the cinematic postcard and, in particular, what Fredric Jameson terms 'glossiness': an aesthetic framing and blending of elements from the past.

At the start of the 1990s, Jameson wrote of the 'enfeeblement of historicity in our own time' (1990: 131). For Jameson, 'historicity' meant a 'capacity to organize and live time historically' (1991: 284). Put another way, historicity is the ability to detach ourselves from the immediacy of the present and to perceive it as temporally contingent, as though with hindsight. Jameson sees what he terms 'nostalgia film' (or period piece) as a compensation for the diminished historicity of the late twentiethcentury, 'a glossy fetish in the service of that unsatisfied craving' (1990:131). He observes that in the nostalgia film, the past is transformed into a commodity for consumption by the spectator. This much is the case, I suggest, in both the Minnelli and Allen films discussed below, despite their complex temporalities and different epochs. However, Jameson's discussion of the postmodern image espoused by nostalgia films is in fact more apt for the 1951 film than for Allen's 2011 production. To demonstrate this requires a closer look at Jameson's conception of a 'glossy' image. He makes an evocative distinction between colour and glossiness:

Color separates objects from one another [...] Glossiness on the other hand, characterizes the print as a whole, smearing its varied contents together in a unified display and transferring, as it were, the elegant gleam of clean glass to the ensemble of jumbled objects [...] which are arranged together as a single object of consumption by the camera lens.

The glossy image becomes homogenous, made into one thing behind the sheen of the pane. Jameson expands on this idea of viewing the past 'behind glass' in a compelling footnote. He refers to the assassination scene in The Conformist (Bertolucci, 1970) as an allegory of the postmodern aesthetic, which is revealed, 'in that rolled-up window of the locked car door from behind which the protagonist observes the pleading, outraged desperation of his lover even as she pounds against it' (1990: 236). Here Jameson suggests that however the past may protest against our consumption of it in its glossiness, it does so mutely, powerlessly. It is safely behind a window - a screen - and we are immune to the unpalatable truths it may hold. This image of framing and 
screening the past highlights the relation between cinematic postcards and the tourist gaze more broadly, for, as Urry and Larsen point out: 'The typical tourist experience is anyway to see named scenes through a frame, such as the hotel window, the car windscreen or the window of the coach.' (2011: 113).

While the city postcard is typically associated with topographical views, I argue that their key function is to bring together different elements from the past into a cohesive, nostalgic and consumable image of contemporary urban space. Just as early postcards and cinema harnessed nostalgic presentations of both old and new structures, to temper anxiety about the modern city, so the cinematic postcard wields nostalgic 'gloss' to diffuse a temporal anxiety about the loss of historicity, or the inability to perceive the present with 'hindsight'. Thus cinematic postcards encompass not only views of the city but, more specifically, a multitude of sites, monuments, icons, figures, names, images and sounds associated with history and cultural heritage, brought together in a glossy, timeless image of place. Cinematic postcards thus draw on similar framing and screening strategies to those in Jameson's 'nostalgia film' but with a less historically specific sense of epoch, since in the 'timeless' image multiple moments from the past may be brought together.

\section{Postcard Openings: Continuities and Discontinuities}

Analyses of An American in Paris and Midnight in Paris help to nuance the concept of cinematic postcard and the historically contingent modes of touristic consumption it implies. Both films offer audiences the city as a pleasurable and touristic spectacle. Both draw on the iconic topography of Paris as inextricable from its cultural past, to create images as familiar as postcards. Analysis of these two films, however, demands an expanded conception of the cinematic postcard that emphasises the commodification of the past and condensation of time in the postcard image. Made sixty years apart, An American in Paris and Midnight in Paris offer striking parallels, revealing the long history of the cinematic postcard. They differ, however, in their touristic presentation of location, as well as in the way the past is incorporated into and commodified by the visual and conceptual space of the film.

Both films construct a complex relation between authenticity and fantasy. They are overtly fictional, yet depend upon the spectator's recognition of Paris as a familiar and appealing location. An American in Paris is a musical, shot almost entirely in the studio. Its plot traces the tribulations of ex-G.I. painter Jerry Mulligan (Gene Kelly) as he negotiates romantic relationships with a mysterious, young French woman and an attentive American heiress. As was common in Hollywood musicals, the studio sets and conventionalised moments of breaking into song and dance are not the only moments of departure into fantasy. A further level that, as Jane Feuer says, 'places a secondary, more stylized fictional world into a primary, less stylized fiction' (Feuer 1982: 68) occurs in the famous 17-minute ballet towards the end of the film, whose premise is the heartbroken protagonist's fantasy of a dance through Paris in pursuit of love. The settings of the ballet draw heavily and explicitly on Paris's cultural heritage, which also more subtly informs the studio decors in the 'real' world of the film.

In Midnight in Paris, the primary fiction is the supposedly 'real' world of luxury tourism and international business travel (a father-in-law doing a deal in Paris). As with the earlier film, there is a 'secondary, more stylized fictional' world, which in this case is connected to the first diegetic level by the chiming of midnight. This marks the moment when the self-professed 'Hollywood hack' protagonist Gil (Owen 
Wilson) is able to access 1920s Paris thanks to a convenient taxi d'époque. Although An American in Paris 'privileges cinematic storytelling above realism' (Harris 2015: 56), the makers of the film were nevertheless concerned with questions of authenticity, and intended a level of accuracy in the studio reconstruction of Paris, employing advisors to that end (Harris 2015: 50-1). In Midnight in Paris, on the other hand, shooting on location appears to bring us more obviously into contact with real sites in Paris. Indeed, although the film's production designer Anne Seibel oversaw the sophisticated and significant set dressing of the film's 1920s and Belle Époque locations such as the Place Pigalle (Harnel 2012), the impression of an on-location tour with recognisable sites is far more insistent than in the earlier film. The end credits affirm 'shot on location in Paris'. This ostensibly more 'real' profilmic location, however, stands in for an authentic relation to place, giving free rein to the film's self-conscious, playful indulgence in a range of fantasies about the city as a space of pleasure and culture. Tellingly, the first words of dialogue we hear, in voiceoff as the opening credits fade to black, are, 'this is unbelievable!' As Gil enthusiastically attempts to impress upon his fiancée, Ines, the awe he feels in response to Paris, the words simultaneously hint that the film will revel in its emancipation from verisimilitude.

Both films position the spectator as a tourist through their focus on an American protagonist and guide. Equally, both films offer the spectacle of a multilayered fantasy of Paris that depends upon a contrast within the diegesis. They move between the real world and a subjective transport that pleasurably performs the characters' (and our) dreams of a time-travelling immersion into the artistic past of the city. Yet An American in Paris retains the sense that what is circulated and transmitted of Paris through the cinematic postcard originates there and reproduces something of the city. Gene Kelly emphasised the authenticity of the sets, writing to his fan club about An American in Paris:

Well, it didn't work out for us to actually go to Paris for any shooting on $A n$ American in Paris, but the atmosphere and color of that great city have been duplicated exactly and with backgrounds shot by a second unit there, you won't be able to tell it from the real thing.

(cited in Harris 2015: 47)

This is not to suggest that Kelly's fans and the contemporary audience for the film somehow mistook the sets for the actual space of Paris. On the contrary, the film's reception demonstrates that Minnelli succeeded in his aim for Paris to be compelling and 'haunting' rather than 'real', as Sue Harris points out: 'the consensus was that the film surpassed all others in capturing the spirit and popular imagination of the city and its people.' (Harris 2015: 106). But nonetheless authenticity is evoked by the idea of capturing something: the film was perceived to capture and transmit the essence of a place. This is, of course, a crucial aspect of the traditional postcard. No matter how gaudy or embellished, argues Naomi Schor, 'they create, however tenuously, a direct link between the viewer and the viewed' (1992: 237). This is because, as both photograph and missive, the urban postcard is supposed to preserve place photographically and then to transmit this elsewhere, as a tangible token of the site witnessed by the tourist. Midnight in Paris does not function on the model of capture and transmission but rather offers the spectator something more like a browse-able collection of typical images: the pure reproducibility of total tourism. An analysis of the opening sequences of the two films helps to illustrate this important similarity (the 
condensation of history into a postcard image for touristic consumption) and difference (reproduction of place versus place as defined by reproducibility).

Both An American in Paris and Midnight in Paris, like many films about the French capital, begin with establishing sequences that offer a touristic perspective. Like the high-angle boulevard view behind the credits of The Last Time I Saw Paris (Brooks, 1954), or the classic photographs by Brassaï, Doisneau et al that open Forget Paris (Crystal, 1995), both Minnelli and Allen evoke from the start a Paris familiar from the international circulation of postcards. They offer panoramic views of sites and monuments often associated with the city by its visitors. After the credits, with their tricolor ribbon and fleur-de-lys stamp of Frenchness, An American in Paris opens with a series of seven panoramic shots that sweep across the Place de la Concorde (two shots), the Tuileries, the Place de l'Opéra, the Pont Alexandre III, the Arc de Triomphe and the Île Saint-Louis, moving from place to place with camera movement that transitions through dissolves. Some of the very few shots in the film that were actually filmed in Paris, these panoramas take us from the central locus of American tourism on the Right Bank, to Jerry Mulligan's (studio-built) home on the Left Bank. While the predominantly high angles create a postcard-like view of famous Parisian monuments, the movement of the camera animates the postcard scenes, allowing the eye to take in broader swathes of the city than a still frame allows, giving the impression of a mobile tour.

The jaunty orchestral music, continuing from the credit sequence, emphasises the dynamism of the image before quietening to underscore the shifts in tone of the main character's introductory voiceover. Whereas Midnight in Paris proclaims, 'this is unbelievable', Jerry Mulligan's voice informs us that 'this is Paris,' making an ontological claim for the film's setting that accords with the actual footage shown. Yet the sequence is more concerned with the transmission of an ideal of Paris than establishing ontological realism: what Paris 'is' does not only consist of boulevards, bridges and fountains, but also its romantic atmosphere and artistic legacy. While Jerry's dutiful tone of voice mimics a tourist brochure as he lists Paris's superiority for painters, 'for study, for inspiration and for living', straight afterwards he is dreamily describing the city as 'this star called Paris', while split chords on the harp and slower, lyrical violins echo his romanticism on the score. It is a cue that we are moving towards the Left Bank and Jerry's artistic and subjective world. Another dissolve takes us to a studio reconstruction of a charming Latin Quarter street. It has a distinctive Morris column in the foreground, offering glimpses of striking advertising posters. A cyclist is the only sign of traffic and the newspaper kiosk, flower cart and café awnings all suggest a vision of the city familiar from nineteenth-century paintings. If this is a Paris, 'deliberately shaped to be the place we recognise from the postcards, whether or not we have ever visited', as Harris asserts (2015: 62), then from the outset, this postcard image of Paris is as much about its cultural past as its geographical present. Through the camera movement, the use of dissolve and the voiceover, temporal layers and familiar sites are seamlessly incorporated into this introductory tour across the city.

The pre-credits montage in Midnight in Paris has a broader coverage of Parisian locations in its three-minute duration, taking in the Eiffel Tower, the SacréCœur, a sea of Parisian rooftops, the Moulin Rouge, the Quais and bridges of the Seine and the Champs-Elysées among many other places in its series of 60 shots. Yet while offering us images its present (which of course already enfolds an architectural history into the view), the sequence also hints at Paris's cultural past. The song that provides its languid jazz soundtrack is ' $\mathrm{Si}$ tu vois ma mère' by the American 
saxophonist Sidney Bechet, recorded in 1952 not long after Bechet had moved to Paris. Although less well-known than the wistful 'Petite Fleur' (1951), which made him famous in France, 'Si tu vois ma mère' captures Bechet's fusion of New Orleans 1920s style and the sentimental vibrato-rich melody that has led him to be described as 'the Edith Piaf of the soprano saxophone' (Porter and Ullman 1988: 146). Paris is therefore subtly depicted as a place welcoming to American visitors, something echoed by recurrent glimpses of tourist figures in the Parisian sites seen on the image track: often posing for photos, even looking at postcards. The artistic charm of Paris is thus presented as arising in part from a tourist gaze, and from American culture (something that will be reinforced later when the 1920s artistic scene is shown to have Americans at its heart). By removing diegetic sound, letting the music fill the images, the spectator inhabits a Paris that is at once 1920s jazz age, Bechet's time there in the 1950 s, and the present-day touristic captial: history is condensed and framed for our apprehension. Just as a postcard frames a scene so that it is at once out-of-theordinary and recognisable, so this sequence welcomes us with familiar clichés underpinned by the appeal of a visit to somewhere 'different'.

As in An American in Paris, the later film expands and animates the postcard view, with traffic and passers-by creating visual dynamism in many of the shots. But the mobility of the camera in the musical that helps create a sense of touring from the Right Bank to the Left, is replaced by a mostly-static camera and rapid editing, not dwelling on any shot long enough for us to contemplate its finer details. In so doing, the opening of Midnight in Paris takes us on a tour of the city that is iconographic, temporal and climatic rather than cartographic: we move from day to night, from sunshine to rain and flit from place to place rather than following a route through the city. An American in Paris opens with a journey into a cohesive world of beauty, culture and art, conjured between Jerry's voiceover and the picturesque tour leading to his home: a tourist brochure brought to life through narrative. Midnight in Paris, on the other hand, opens with a slide show with a musical accompaniment. There is no narrative here, only atmosphere and signs: a virtual postcard collection. I will return to this idea of the virtual collection. Firstly, however, it is necessary to elaborate futher on the presentation of the past in the films, and its relation to a nostalgic, commodified consumption of Paris.

\section{Glossy Postcards: The Elegant Gleam of Nostalgia}

If An American in Paris functions as a cinematic postcard, it is one that is emphatically nostalgic, framed to condense the cultural heritage of the city into a glossy, consumable image. The film evokes the city's past through numerous references to impressionist and post-impressionist paintings in its picturesque sets, as well as in Jerry's paintings, which are inspired by Rouault, Lautrec and Utrillo. Angela Dalle Vacche has argued persuasively that art historical references proliferate across the whole film (1996: 21). These allusions are at their most striking and explicit, however, in the ballet sequence near the end of the film, in which the protagonists dance through sets each evoking a painterly vision of Paris. The ballet constructs a blend of vitality and stillness, as well as a harmonious interplay between two and three-dimensional images. Characters who at first appear to be part of a painting seamlessly join in the dance, while others transform from dancers into immobile sets. Some characters, such as the American G.I.s who dance into the Utrillo-inspired Montmartre scene, have shading painted onto their costumes to give the impression that they have emerged from a canvas. Parts of the set designed to 
resemble flat sketches or paintings are shown to have depth that can be moved through and danced around, such as the lamp-posts and obelisk in the sequence inspired by Raoul Dufy's watercolours of the Place de la Concorde, or the steps and archways outside the Opéra. In the Toulouse-Lautrec sequence this extends to the human figures too, incorporating flat cut-outs, tableaux vivants and dancers. This fluidity between dance and stillness, flatness and depth creates a mutable relationship between painting and life, allowing different signifiers of Paris's past to converge in a unified, animated spectacle.

The ballet offers familiar images likely trigger recall in the viewer. As Harris tells us, 'the design method for the decor was imitative, using identifiable works of art as source material' (2015: 98). Yet as Dalle Vacche points out, 'no specific painting is accurately cited in its entirety' (1994: 24). Just as in the sets in the rest of the film, there are many diffuse references to artists associated with Paris, such as a pink-andgold-hued hint of Van Gogh's famous, swirling impasto sky in The Starry Night (1889) in the Opéra sequence décor. The references are cohesively integrated so that disparate elements do not seem out of place, while sophisticated lighting and editing allow smooth movement between the various painterly stage sets. This fluidity has a unifying as well as commodifying effect: framed by the narrative of Jerry's artistic influences, frustrated hopes for his life in Paris, and heartbreak over Lisa, the multiplicity of signs is brought together in a pleasurable and apparently seamless dance. Despite the ballet's apparent departure, as Pam Cook has it, from 'the business of reading the narrative' (2007: 108), the narrative frames the excessive spectacle of the sequence. This, along with the magical smoothness of its various transitions, creates an emulsifying effect similar to the sheen of the glass in Jameson's footnote description of glossy nostalgia. Harris points out that, like Jerry Mulligan, 'we are required to be dazzled, but not alienated by what we see: history, geography and architecture are thus knowingly and comfortingly collapsed into visual quotation' (2015: 62). The effect is consistent throughout the film and indeed depends on its wholeness as a work. Despite its technicolor, chromatic abundance, An American in Paris creates a unified display from its multiple allusions to images and artefacts from the past. Such unification is, on one level, just what one expects from classical filmmaking, but here it collides with the age of mass tourism: like a postcard, the musical becomes the epitome of a touristic consumption of time and place. Just as in Jameson's conception of 'glossiness', the seamlessness of the film's nostalgic vision of Paris is an instrument of commodification of the past, understood as something that the viewer, as cine-tourist, craves.

Scholars have related the postcard-like representation of Paris in the film to its historical context in various different ways. Both Dalle Vacche and Vanessa Schwartz identify efforts to resolve the apparent conflict between French art and Hollywood entertainment, through an aesthetic that unites European cultural heritage with Hollywood conventions (Dalle Vacche 1996: 14-16, Schwartz 2007: 34). However Harris astutely observes that, like other films made in this immediate post-WWII context, the film's touristic vision of Paris is in stark contrast to the unstable and even 'desperate' city documented in other ways at the time (48). This contrast, I suggest, reveals the context of tourism to be crucial: for both domestic and international audiences the film offered the chance to visit an ideal, nostalgic Paris, tempering the anxities of the present. Cook informs us that the US press book for the film advised on commercial tie-ins relating to fashion, commodities and tourism: travel, but also what one might call cultural tourism, such as language lessons, dance and art classes (2007: 117). Both in its aesthetics and its marketing, in other words, An American in 
Paris performed the commercialisation of 'transport' - in all its senses - that would come to define the global sign industries as they dominated the latter part of the twentieth century.

Midnight in Paris also manifests a nostalgic relation to historic, artistic Paris as a site of pleasure for protagonist and spectator alike. Yet its relation to nostalgia is quite different, for it is much more self-conscious and narratively explicit. Gil's timetravelling excursions into 1920s Paris are, we discover, a symptom of his 'golden age thinking', as the pompously pedantic character Paul puts it: 'the erroneous notion that a different time period is better than the one one's living in'. Initially unconvincing, coming from such a dislikable character, Paul's words contain the seeds of Gil's revelation. When he discovers that the lovely muse Adrianna - whom he meets in the 1920s - dreams of living in the Belle Époque, while the painters Gauguin and Degas imagine that the Renaissance would have been the ideal period to be an artist, Gil realises that he must face up to the realities of his present moment (and be grateful that he has access to antibiotics). Thus the narrative returns Gil from historical fantasy tour, all the better to confront and adapt to the 'real' of the present. To put it another way, Gil is a parodic mise-en-abyme of the postmodern film spectator. He manifests the desire that Jameson identifies in audiences of the nostalgia film, who consume images of the past to satisfy their cravings for historicity. Like a film spectator, Gil is explicitly a tourist: he travels in both space and time but is ultimately reconciled to the end of his vacation by returning to the present with a fresh perspective on life.

Yet the 'present' we experience in Midnight in Paris is nothing like the world of the spectator in 2011 (let alone today), even imagining for a moment a spectator as privileged as the characters we see on screen. There is something missing from this 'present': no smartphones, no Google, no Wikipedia, no social media. It is as though the Internet does not exist. Apart from a fleeting glimpse of Ines's phone in two scenes, the viewer is treated to a 'digital detox', in which the creamy lustre of the image, in scenes of plush hotel rooms, expensive restaurants, light-filled museum spaces and the quais of the river Seine can be enjoyed without the intrusions of digital connectivity. Gil is able to get lost in the streets and needs help with translation from a human: the beautiful Carla Bruni Sarkozy (playing a guide at the Musée Rodin). We never see Gil at a computer, only scribbling on a notepad or clutching a paper manuscript of his novel. Nostalgia, in other words, is even more thoroughly at work in the film than first appears: it is the present that we see, postcard-like, behind the elegant gleam of the window pane.

I want to suggest, however, that while sustaining this nostalgic disavowal of the contemporary, mediatised relation to place, Midnight in Paris ultimately reflects distinctive features of 'total tourism' in the Internet era. There is no contradiction here, for the nostalgic digital cleansing of present-day Paris only further contributes to the collectable quality of its images, rather in the way that nostalgic photographic filters contribute to the popularity of images shared on Instagram (Bakhshi et al 2015: 9). Consider the geometric vistas of Versailles accompanied by Paul's bland architectural commentary, the low-angle shot of Rodin's statue of The Thinker, carefully identified both by a glimpse of the plinth and in the guide's dialogue, or the view of Monet's Water Lily series in the Musée de l'Orangerie, which like the virtual tour on the museum's real-life website is conveniently devoid of other visitors. ${ }^{4}$ Like glossy postcards, these images in the film minimize modern intrusions and quell anxiety about the overwhelming experience of modern technology; yet like virtual collectibles, they are carefully demarcated, captioned, offered up for our capture, presented as potentially desirable objects of consumption for the viewer. Unlike in $A n$ 
American in Paris, recognisable features of touristic Paris are not framed for cohesiveness and fluidity. On the contrary, the majority of significant or collectable tourist images are flagged-up, visually and in the dialogue, as though tagged with metadata for search engine optimization.

\section{Virtual Collections and the 'You Loop'}

In Midnight in Paris, the abundant evocations of the literary and artistic heritage of Paris become consumable signs for the spectator-as-tourist to collect and enjoy virtually, like the 'partially actualized' collections of possessions that Knott and Molesworth identify with virtual digital consumption. This is most obvious in Gil's encounters with famous figures of the past, such as Cole Porter, Scott and Zelda Fitzgerald, Josephine Baker, Salvador Dalí, Man Ray, Luis Buñuel, Gertrude Stein, Alice B. Toklas, Djuna Barnes and Pablo Picasso (among others). All provide familiar outlines: names, traits or tics for the spectator to register. Unlike in An American in Paris, where allusion is smoothly integrated into the flow of movement, image and narrative, Allen underscores the function of the allusions as signifier or citation. Often this involves a literal labelling, with Gil emphatically repeating the name, in a duly awestruck tone, of the artistic or literary figure he encounters. With major figures such as the Fitzgeralds and Hemingway, the labelling through dialogue is underscored by shot-reverse-shot editing to emphasise Gil's amazed recognition. These strategies mean that whether or not spectators recognise the sites, figures or names in question, they are aware that they are in the presence of a collector's item that is supposed to be known, optimized for a later Google search. This process of tagging is reinforced elsewhere in the script. For example, when Gil first mentions his encounters with the Fitzgeralds and Hemingway to Ines, she replies, 'is that what you were dreaming about, your literary idols?', offering a searchable clue for anyone unfamiliar with the names.

Whereas, both in the ballet sequence and throughout the film, the narrative of An American in Paris fashions the elements of touristic interest into a cohesive whole, the narrative of time-travelling tourism in Midnight in Paris contributes to the iconic seriality of its collectibles. Gil's astonishment as he slowly realises he has been transported into the past allows his stunned reactions to signal the presence of a significant feature of the Parisian environment. The scene at Bricktop's, for example, uses mise-en-scène, editing and music to direct attention to an iconic figure. It begins with the camera moving from left to right, taking in the atmosphere of Ada 'Bricktop' Smith's famous nightclub, before settling on a shot of Josephine Baker (Sonia Rolland) dancing. Baker is highlighted visually: her white beaded dress and feathered stole stand out against a frame of onlookers wearing predominately dark clothing, while her undulating mobility contrasts with their relative stillness. We then cut to a reaction shot of Gil, his face expressing dumbfounded amazement, before tracking his gaze to capture Zelda Fitzgerald giggling into her glass of Champagne, finally returning to the medium close-up of Gil watching Baker as he relaxes into the moment. The emphasis on Gil's reaction in this sequence has the narrative role of settling him into a bemused acceptance of the time travel experience. Yet it also underscores the iconicity of Baker as a noteworthy sight in this heritage tour of Paris. The soundtrack adds a further collectable object: Josephine Baker's voice. Diegetic sound in the sequence is muted, allowing the music to pervade the scene. The song, a recording of Baker singing 'La Conga Blicoti' (1936), permeates the interior space, with both onlookers and Baker herself moving in sync with its rhythms; Gil, too, 
eventually seems to nod his head to the beat. Yet it is not strictly diegetic: Baker is not seen singing, and in any case the song is not from the 1920s but rather the later film Princesse Tam-Tam (Gréville, 1935). The Cuban-French musical style and colonial, exoticising lyrics tie the song to Baker's enduring image as exotic dancer, even if in the scene she is not shown in her famous banana skirt. On the one hand, the song functions as a further sign of her iconic presence, yet by being detachable both from the diegetic world and temporal specificity it is also simply another collectible for the audience. ${ }^{5}$ Indeed, comments beneath several postings of 'La Conga Blicoti' on YouTube indicate that many viewers sought out the song after having watched Midnight in Paris. ${ }^{6}$

In an enthusiastic review of Allen's film, Amy Porter highlights precisely this collector's pleasure, from the perspective of the connoisseur:

I have seen it three times, to make sure that I didn't miss a single one of the cameo appearances of artists, novelists, musicians of the Jazz Age, all that Paris in the '20s ambience, the dark wood panels in the bars, the almost careless references to the heroes of the era, the one-liners that made me laugh because they recalled lines in books I have read, music I have heard, or other films I have seen.

(Porter 2012: 27)

The term cameo is apt for its connotation of recognition based on a familiar outline. Its common, figurative usage is derived from miniature portraits in white relief on a contrasting background - just like the mise-en-scène of Josephine Baker dancing. Such cameo appearances within the film figure recognisable and nameable images associated with Parisian history, primarily the late 1920s but also, later on, the Belle Époque. More striking still is Porter's insistence on capture: not wanting to 'miss a single one'. This is quite a different sort of capture from the one discussed above in relation to An American in Paris, where an essence of Paris (not so much its physical reality as its atmosphere and history) was presumed to be transmissable through a cinematic tour. In Midnight in Paris it is the spectator who is encouraged to capture the cameos, visual clues and one-liners. This recalls Stewart's distinction between the souvenir and the collection, evoked above, where the collection effaces origins in favour of the pleasurable capture of objects. In the information age, however, our patterns of consumption increasingly involve the partial actualisation of objects: we amass them online in virtual collections. We might also think here of the locationbased augmented reality game Pokémon Go, which involves the capture and collection of creatures appearing on a smartphone screen, as though they are in the same real-life location as the player. In offering a fantasy of Paris as a series of vintage, virtual collectibles, Midnight in Paris reflects our transition into total tourism: place is no longer only, 'a modular product [...] itemised for tourist consumption' as Liz says of the cinematic postcard's use of famous monuments (2014: 8), but rather both place and history are translated into endlessly circulated and potentially collectable information.

Focusing on one of the myriad references in Allen's film sheds further light on the way in which cultural heritage becomes detached from its origins and collectable. For both Gil and the spectator, Ernest Hemingway acts as a signifier of literary Paris, offering Gil a yearned-for affiliation (he refers to him by his later nickname, 'Papa') and the spectator the possibility of pleasurable recognition. Allison Nadja Field attests that Ernest Hemingway, 'has himself become a monument - a site for contemporary 
tourists' (Field 2010: 94) and his presence as collector's item in Midnight in Paris supports this idea. However in its transportation into Woody Allen's film, the 'moveable feast' has lost something in transit. Hemingway is first cited when Gil is enthusing about his fantasy of inhabiting Paris through a series of clichés: 'strolling along the left bank with a baguette under my arm, headed to Café Flore to scribble away on my book. What did Hemingway say? He called it a moveable feast.' The incongruity of the quotation is striking, since Hemingway's phrase emphasises Paris's portability in memory, while Gil uses it as a justification for his urge to move to Paris. The superficiality of the citation is reinforced later by the character of Hemingway himself. At the Fitzgeralds' party, a tipsy Hemingway arrives, proclaiming, 'isn't this little Parisian dream a moveable feast?' What can this moveable consumption possibly mean here, in Paris, for the characters? The phrase has become part of a collection, divorced from its original context and significance. It functions only to trigger recognition in Gil and the spectator, tagged for our capture. Yet this very process indicates the profound 'moveability' of a Paris translated into information, on which we feast through virtual windows.

Waking after his first tour into the 1920s, Gil gushes excitedly that Zelda Fitzgerald is 'exactly as we've come to know her'. The humour of this moment is in the closed loop of representation and recognition: figures from the past are exactly as Gil pictures them because they are (presumably) produced by his fantasies, and the circulating representations of them from which those fantasies derive. The film comes close, here, to parodying the way as spectators we are engaged in the same game of recognition rather than discovery. This loop of fantasy and fulfilment has a long history in tourism, for as Stewart observed in 1984, tourist souvenirs, 'increasingly tend in both form and content to be shaped by the expectations of the tourist market that will consume them' (149). But by 2011, when Midnight in Paris was released, we had already entered the era of the 'filter bubble' as identified by Eli Pariser, in which stored online information results in an increasingly personalized web browsing experience, leading to an ever-narrower horizon of discovery:

You click on a link, which signals an interest in something, which means you're more likely to see articles about that topic in the future, which in turn prime the topic for you. You become trapped in a you loop.

(Pariser 2011: 125)

This arises, of course, in the context of the monetisation of the internet as digital archive, what Trond Lundemo has described as, 'the calculability of public interest and potential consumption' (2014: 34). Cinematic tourism, I argue, reflects and is implicated in this wider culture of 'information determinism, in which our past clickstreams entirely decide our future' (Pariser 2011: 135). Midnight in Paris is a useful example because it both self-consciously highlights and involves the spectator in a form of cine-tourism as information capture, with its potential to descend into a closed 'you loop'.

The cinematic postcard, far from being a distinctive feature of contemporary cinema, is a persistent but historically contingent mode of consuming the city through cinema. The example of An American in Paris shows that its early, postwar form already anticipated postmodern aesthetics in its glossy commodification of the past. Midnight in Paris is a striking example of a contemporary cinematic postcard that illuminates and reflects the concept of 'total tourism', in which the city is consumed through virtual collections. In emphasising the capture of reproducible signs, rather 
than the preservation and transmission the essence of a city, the film reveals how our relation to authenticity has shifted: mediation is seen as desirable rather than distorting. At the same time, the nostalgic gloss cast over the present-day scenes comfortingly disavows the technological instruments of such mediation. There are many examples of cinematic postcards of Paris throughout film history, from Billy Wilder's Love in the Afternoon (1957), through William Huyck's French Postcards (1979), to Julie Delpy's self-conscious and parodic Two Days in Paris (2007). While such examples show diverse approaches to commodifying the topography and cultural heritage of Paris, their common thread lies in the postcard's offer of nostalgia as a way of responding to the anxieties provoked by the urban environment. In the troubled, unstable Paris of the early postwar years, the tourist gaze of cinema provided a cohesive image constructed from a selective, cultural past. In the twentyfirst century, a nostalgic fantasy of Paris as a locus of analogue art, romance and history, always available for virtual collection, screens out anxiety about the allconsuming world city of total tourism.

\section{References}

Allen, W. (2005), Match Point, United Kingdom/Luxembourg: BBC/Jada Productions.

Allen, W. (2011), Midnight in Paris, Spain/USA: Mediapro/Versátil Cinema/Gravier Productions.

Alloula, M. (1987), The Colonial Harem (trans. Myrna Godzich and Wlad Godzich), Theory and History of Literatures, Vol. 21, Manchester: Manchester University Press.

Assayas, O. et al. (2006), Paris, je t'aime, Switzerland/France: Victoires International/Pirol Film Productions.

Bakhshi, S., Shamma, D., Kennedy, L. and Gilbert, E. (2015), 'Why We Filter Our Photos and How It Impacts Engagement', comp.social lab, Georgia Tech, http://comp.social.gatech.edu/papers/icwsm15.why.bakhshi.pdf . Accessed 1st October, 2016.

Baudrillard, J. (1998), The Consumer Society: Myths and Structures, London: Sage.

Bertolucci, B. (1970), Il Conformista (The Conformist), Italy/France/West Germany: Mars Film Produzione/Marianne Productions/Maran Film.

Brooks, R. (1954), The Last Time I Saw Paris, USA: Metro-Goldwyn-Mayer.

Bruno, G. (2002), An Atlas of Emotion: Journeys in Arts, Architecture and Film, London: Verso.

Cook, P. (2007), 'An American in Paris (1951)', in Mandy Merck (ed.), American First: Naming the Nation in US Film, pp.105-19.

Corrigan, P. (1997), The Sociology of Consumption, London: Sage.

Dalle Vacche, A. (1996), Cinema and Painting: How Art is Used in Film, Austin: University of Texas.

Delpy, J. (2007), Two Days in Paris, France/Germany: Polaris Films.

Diffrient, D. S. (2015), 'Collecting Views and Visions of the City: Episode Films, Paris vu par... and "Postcard Cinema"', Quarterly Review of Film and Video, 32: 7, pp. 589-610.

Feuer, J. (1982), The Hollywood Musical, London: Macmillan.

Field, A. N. (2010), 'Expatriate Lifestyle as Tourist Destination: The Sun Also Rises and Experiential Travelogues of the Twenties', in M. Cirino and M. P. Ott (eds), Ernest Hemingway and the Geography of Memory, Kent, OH: Kent State University Press, pp. 83-96. 
Friedberg, A. (2006), The Virtual Window, Cambridge MA and London: The MIT Press.

Fussell, P. (1980), Abroad: British Literary Traveling Between the Wars, Oxford: Oxford University Press.

Greville, E. T. (1935), Princesse Tam-Tam (Princess Tam-Tam), France: Productions Arys.

Groys, B. (2008), 'The City in the Age of Touristic Reproduction', in Art Power, Cambridge, MA and London: The MIT Press, pp. 100-109.

Harris, S. (2015), An American in Paris, London: Palgrave/British Film Institute.

Hemingway, E. (2004), A Moveable Feast, London: Arrow Books [First publ. 1936].

Higson, A. (2003), English Heritage: English Cinema: Costume Drama since 1980, Oxford: Oxford University Press.

Huyck, W. (1979), French Postcards, France/USA/Germany: Geria Film. Jameson, F. (1990), Signatures of the Visible, New York \& London: Routledge. (1991), Postmodernism: Or, the Cultural Logic of Late Capitalism, Durham, NC: Duke University Press.

Jurgenson, N. (2012), 'The Facebook Eye', The Atlantic, $13^{\text {th }}$ January, https://www.theatlantic.com/technology/archive/2012/01/the-facebookeye/251377/. Accessed $1{ }^{\text {st }}$ June, 2017.

Liz, M. (2014), 'From Europe With Love: Urban Space and Cinematic Postcards', Studies in European Cinema, 11:1, pp. 3-13.

Lundemo, T. (2014), 'Archives and Technological Selection', Cinémas, 24:2-3, pp.17-39.

MacCannell, D. (1973), 'Staged Authenticity: Arrangements of Social Space in Tourist Settings', American Journal of Sociology, 79:3, pp. 589-603.

Mazierska, E. and Walton, J.K. (2006), 'Tourism and the moving image', Tourist Studies, 6:1, pp. 5-11.

Minnelli, V. (1951), An American in Paris, USA: Metro-Goldwyn-Mayer.

Molesworth, M. and Knott, J.D. (2012), 'Digital Virtual Consumption as Transformative Space', in R.W. Belk, R. Llamas (eds), The Routledge Companion to Digital Consumption, London and New York: Routledge, pp. 223-234.

Pariser, E. (2011), The Filter Bubble: What the Internet is Hiding from You, London: Penguin.

Phillips, A. (1999), 'Performing Paris: myths of the city in Robert Siodmak's émigré musical La Vie Parisienne', Screen 40:3, pp. 257-276.

Porter, A. (2012), 'Midnight in Paris: A Moveable Feast', Queen's Quarterly: A Canadian Review, 119:1, pp. 26-33.

Porter, L. and Ullman, M. (1988), 'Sidney Bechet and His Long Song', The Black Perspective in Music, 16:2, pp. 135-50.

Prochaska, D., and Mendelson, J. (eds) (2010), Postcards: Ephemeral Histories of Modernity, University Park: Pennsylvania State University Press.

Rabinovitz, L. (2012), Electric Dreamland: Amusement Parks, Movies and American Modernity. New York: Columbia University Press.

Roberts, L. (2010), 'Projecting Place: Location Mapping, Consumption and Cinematographic Tourism', in R. Koeck and L. Roberts (eds), The City and the Moving Image: Urban Projections, Basingstoke: Palgrave Macmillan.

Silverman, J. (2015), Terms of Service: Social Media and the Price of Constant Connection, New York: Harper.

Schor, N. (1992), “'Cartes Postales”: Representing Paris 1900', Critical Inquiry, 18:2, pp. 188-244. 
Schwartz, V.R. (2007), It's So French! Hollywood, Paris, and the Making of Cosmopolitan Film Culture, Chicago and London: University of Chicago Press.

Siodmak, R. (1936), La Vie Parisienne, France: Nero-Film.

Stewart, S. (1984), On Longing: Narratives of the Miniature, the Gigantic, the Souvenir, the Collection, Baltimore and London: Duke University Press.

Tzanelli, R. (2007), The Cinematic Tourist: Explorations in globalisation, culture and resistance, London and New York: Routledge.

Urry, J. and Larsen, J. (2011), The Tourist Gaze 3.0, London: Sage.

Vernalis, C. (2013), Unruly Media: YouTube, Music Video, and the New Digital

Cinema, Oxford: Oxford University Press. doi:

10.1093/acprof:oso/9780199766994.003.0000. Accessed 12 $2^{\text {th }}$ December 2016.

Wilder, B. (1957), Love in the Afternoon, USA: Allied Artists Pictures Corporation.

\section{SUGGESTED CITATION}

McNeill, I. (2017), 'Glossy Postcards and Virtual Collectibles: Consuming Cinematic Paris', Journal of Urban Cultural Studies, 4: 3, pp. ?-?, doi:

\section{Contributor details}

Dr Isabelle McNeill is a Philomathia Fellow in French at Trinity Hall, University of Cambridge, where she teaches French literature and film. She is the author of Memory and the Moving Image: French Film in the Digital Era (Edinburgh University Press, 2010). Her articles and essays on film have addressed questions of cultural memory, urban space, belonging, and relations between cinema and digital media. Her current project is a book for Wallflower Press, entitled The Rooftops of Paris: Cinematic Perspectives. She also participates in the promotion of film culture through her work with the Cambridge Film Trust, which she co-founded. The Cambridge Film Trust is a registered charity that runs the Cambridge Film Festival, along with other events in the UK.

Contact: Trinity Hall, University of Cambridge, Cambridge, CB2 1TJ, United Kingdom.

E-mail: imm21@cam.ac.uk

Isabelle McNeill has asserted her right under the Copyright, Designs and Patents Act, 1988 , to be identified as the author of this work in the format that was submitted to Intellect Ltd.

\footnotetext{
${ }^{1}$ See for example Bruno 2002: 77-8, Roberts 2010, Tzanelli 2007.

${ }^{2}$ See also Higson 2003: 56-63.

${ }^{3}$ I am grateful to Milosz Rosinski for bringing Groys's essay to my attention.

${ }^{4}$ See http://www.musee-orangerie.fr/en/article/water-lilies-virtual-visit

${ }^{5}$ This exoticisation of Baker as a collectable figure in the film, albeit subtly conveyed, recalls Malek Alloula's critique of colonial postcards of Algerian women, in which he exposes both colonial ideology and the eroticization of the female body, 'in order to offer it up to any and all comers from a clientele moved by the unambiguous desire of possession' (1987: 5).

${ }^{6}$ See for example: https://www.youtube.com/watch?v=fffEgkf_b7I
} 